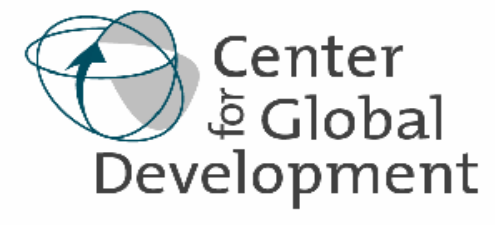

\title{
Aiding Transparency: What We Can Learn About China ExIm Bank's Concessional Loans \\ By Paul Hubbard
}

\begin{abstract}
The Chinese government, through the China Exim Bank, is pledging billions of dollars worth of concessional lending to the developing world. More information on these lending practices can be gleaned from Chinese language sources than is readily available in English. However, this material is insufficient to draw more than tentative conclusions about the real nature and scope of China's concessional lending. Over 48 countries have agreements with China for concessional loans. An average loan of US\$20-30 million is made available to Chinese exporting firms to develop infrastructure and facilities in developing countries. While these loan sizes are not huge when compared to other aid flows, China's status as the dominant lender of concessional loans amongst some recipients makes this program significant. Finally, it is still not clear if the loans could be considered Official Development Assistance according to the DAC definition.
\end{abstract}

The Center for Global Development is an independent think tank that works to reduce global poverty and inequality through rigorous research and active engagement with the policy community. Use and dissemination of this Working Paper is encouraged, however reproduced copies may not be used for commercial purposes. Further usage is permitted under the terms of the Creative Commons License. The views expressed in this paper are those of the author and should not be attributed to the directors or funders of the Center for Global Development. 


\title{
Aiding Transparency: What We Can Learn About China Exim Bank’s Concessional Loans
}

\author{
By Paul Hubbard \\ Candidate for Master of Arts in International Relations, Maxwell School for Citizenship \\ and Public Affairs, Syracuse University \\ Graduate Intern, Center for Global Development \\ Foreword by Carol Lancaster \\ Visiting Fellow, Center for Global Development
}

Page 1 of 17 


\section{Foreword}

\section{Carol Lancaster}

Paul Hubbard has filled in another piece of the puzzle we are all trying to solve - how does the Chinese aid system work? The way Chinese aid is organized and functions is not transparent - probably not even to the Chinese. But it is important for specialists in foreign policy and international development to understand it because the Chinese are expanding their aid rapidly in Africa, Latin America and elsewhere and are likely to have a considerable economic and political impact. It is also essential for us to know whom we should talk to in Beijing as we explore Chinese policies, purposes and opportunities for collaboration.

Paul Hubbard describes one of the mechanisms the Chinese government uses to implement its aid - the Chinese Export-Import Bank - and helps illuminate the role of this important institution. It is one more useful effort in an on-going program at the Center for Global Development to expand our understanding of the world's most prominent rising power and important player in worldwide development. 


\section{Aiding Transparency: What We Can Learn About China ExIm Bank's Concessional Loans}

Development experts interested in China's rapidly expanding development assistance, particularly to Africa, have been frustrated at what appears to be a lack of transparency in the make up and amount of Chinese official development assistance. Western scholars and policy makers have had to work with estimates and guess work and Chinese officials appear unable in interviews to provide more comprehensive figures. ${ }^{1}$

Chinese statistics tend to conflate concessional and non-concessional lending into a single figure when reporting the size of China Exim Bank loans, making it difficult for researchers to distinguish where loans are being provided on a concessional or non-concessional basis. ${ }^{2}$ It is also unclear just what the difference in terms might be.

Recently, a Chinese diplomat claimed to me that Chinese aid is in fact very transparent, and that details are published in Chinese language sources. This argument suggests that it is a 'veil of ignorance' rather than a 'lack of transparency' that frustrates Western aid analysts.

This paper tests that proposition by reviewing China's concessional lending program provided through the China Exim Bank, relying on Chinese language sources from the websites of the Ministry of Commerce, China Exim Bank, the Ministry of Foreign Affairs, and official news outlets like the People's Daily and Xinhua. Using these sources, it is possible to find greater detail than in English language sources of the recipients, sectors and amounts of Chinese concessional lending.

For example, reporting in April on China Exim Bank's 2006 soft loan to Eritrea, Reuters ${ }^{3}$ sole source appears to be the Eritrean information ministry's website, noting that the loan "did not specify what the money was destined for" and that "[o]fficials could not immediately be reached to clarify". When the final agreement was signed in July 2006, the Africa News noted that the loan "would be channeled to modernize the telecommunications infrastructure in Eritrea."4

On the Chinese side, some detail of the agreement on the websites of the Ministry of Commerce, the Ministry of Foreign of Foreign Affairs, China Central Television, as well as various media outlets. While the terms of the loan are not reported, the size of the loan is confirmed (166 million Renminbi) and some details of the 18 month fixed and wireless network projects for which the loan provided. The project's aim is to increase telephone subscription in Eritrea from 1.5 to 6.5 per cent. (Appendix A)

\footnotetext{
${ }^{1}$ Brautigam 2007

${ }^{2}$ Brautigam 2007

${ }^{3}$ Harris 2006

${ }^{4}$ Africa News 4 July 2006
} 


\section{How does the Concessional Loan Program Work?}

Since its foundation in 1994, the China Exim Bank (中国进出库银行) has provided concessional loans (优惠贷款) to developing countries on behalf of the Chinese government. The concessional lending program is separate from China's other activity, and is also managed separately from the Bank's sizeable commercial lending facilities.

The China Exim Bank website explains, in English, ${ }^{5}$ Chinese $^{6}$ and French, ${ }^{7}$ the policy and procedures behind the Chinese Government Concessional Loan. Not surprisingly, the most information is provided in Chinese. Even the schematic diagram on the Chinese language site is more detailed than the English version. (See Appendix B)

The borrowing country government submits an application to China Exim Bank, which then provides a recommendation to the Chinese Ministry of Commerce. If the recommendation is accepted, there is then a bilateral framework agreement signed between the borrowing government and the People's Republic of China.

Once this state-to-state framework agreement has been signed, the China Exim Bank can then sign loan agreements that conform to this framework agreement on a project by project basis. This is usually signed by a President or Vice-President of the Bank and a minister from the borrowing country's government. Each agreement provides an opportunity for a high profile signing ceremony.

These signing ceremonies are often reported in Chinese and announced on an official government website. By reviewing reports of the ceremonies and the list of treaties entered into by China during the year we can discover some details of China's lending program. They do not provide us with details of when the loan was disbursed, repaid or forgiven, but they do provide an official starting point from which particular projects could be followed up.

According to the schematic diagram, a Chinese exporter contracts with a foreign executing agency, which it then invoices based on the terms of the contract. The foreign executing agency provides a report to the foreign government, which then makes an application to the China Exim Bank to disburse the loan. The loan is then disbursed from the China Exim Bank to the Chinese contracting agency. The foreign government is responsible for the payment of interest and fees to China Exim Bank.

\section{Who is borrowing from the China Exim Bank?}

In 1997, the China Daily reported that since 1995 the Exim Bank had provided 1 billion renminbi (US \$138 million) in concessional loans to fund 15 projects in 10 countries. Sudan, Kenya, Equatorial Guinea, Botswana, Cote d'Ivoire and Gabon were identified as

\footnotetext{
${ }^{5}$ http://english.eximbank.gov.cn/business/government.jsp

${ }^{6} \mathrm{http}: / /$ www.eximbank.gov.cn/yewu/duiwaiyh.jsp

${ }^{7} \mathrm{http}$ ://english.eximbank.gov.cn/business/government-fr.jsp
} 
six of the ten recipients. ${ }^{8}$ In 1998 the China Daily reported that "nearly 30 projects" had been funded by concessional loans, also indicating that Cameroon, Guyana and Papua New Guinea were been recipients. ${ }^{9}$ The People's Daily in 2001 reported that there were 72 concessional loan projects in 36 states. ${ }^{10}$ By the end of 2002, the Chinese claimed 90 projects in 40 states. $^{1}$

Lending activity from 2002-2006 can be partially identified through the Ministry of Foreign Affairs' annual table of bilateral agreements. Many of these agreements are called 'economic cooperation agreements' or 'development loan agreements', which may or may not contain terms for concessional lending. There are 21 bilateral agreements that are explicitly named 'concessional loan framework agreements'. Taking these at face value, we can positively identify 20 additional recipient countries from 21 bilateral agreements with this title (Appendix D). The caveat is that while a framework agreement makes it possible to borrow under the concessional scheme, not all countries that have signed a framework agreement have necessarily received a concessional loan.

Aggregating this data with Chinese government source information detailing when China Exim Bank loan agreements have been signed, we can identify at least 48 states which have framework agreements or have already received concessional loans. This list is incomplete, but gives us a good idea of the geographic range of borrowers.

$\begin{array}{llll}\text { Angola } & \text { Eritrea } & \text { Mali } & \text { Syria } \\ \text { Bangladesh } & \text { Ethiopia } & \text { Mauritius } & \text { Tajikistan } \\ \text { Benin } & \text { Fiji } & \text { Mongolia } & \text { Tanzania } \\ \text { Botswana } & \text { Gabon } & \text { Morocco } & \text { Togo } \\ \text { Cambodia } & \text { Ghana } & \text { Mozambique } & \text { Trinidad and Tobago } \\ \text { Cameroon } & \text { Guyana } & \text { Nigeria } & \text { Tunisia } \\ \text { Congo-Brazzaville } & \text { Indonesia } & \text { Pakistan } & \text { Uzbekistan } \\ \text { Congo-Kinshasa } & \text { Jamaica } & \text { Papua New Guinea } & \text { Venezuela } \\ \text { Cote d'Ivoire } & \text { Kenya } & \text { Philippines } & \text { Vietnam } \\ \text { Djibouti } & \text { Laos } & \text { Samoa } & \text { Yemen } \\ \text { Egypt } & \text { Liberia } & \text { Sudan } & \text { Zambia } \\ \text { Equatorial Guinea } & \text { Maldives } & \text { Suriname } & \text { Zimbabwe }\end{array}$

\footnotetext{
${ }^{8}$ China Daily, 18 May 1998

${ }^{9}$ China Daily, 4 August 1997

${ }^{10}$ People's Daily, 26 February 2001

${ }^{11}$ People's Daily, 28 December 2002
} 


\section{How much is being borrowed?}

Using official Chinese reports of concessional lending signing ceremonies between recipient governments and representatives of the China Exim Bank, it was possible to identify 28 separate concessional lending agreements. These reports typically contain details of the signing ceremony, identifying who signed for each party, the size of the loan, and the sector in which the concessional loan was being provided. Sometimes the Chinese exporter for the project is also identified.

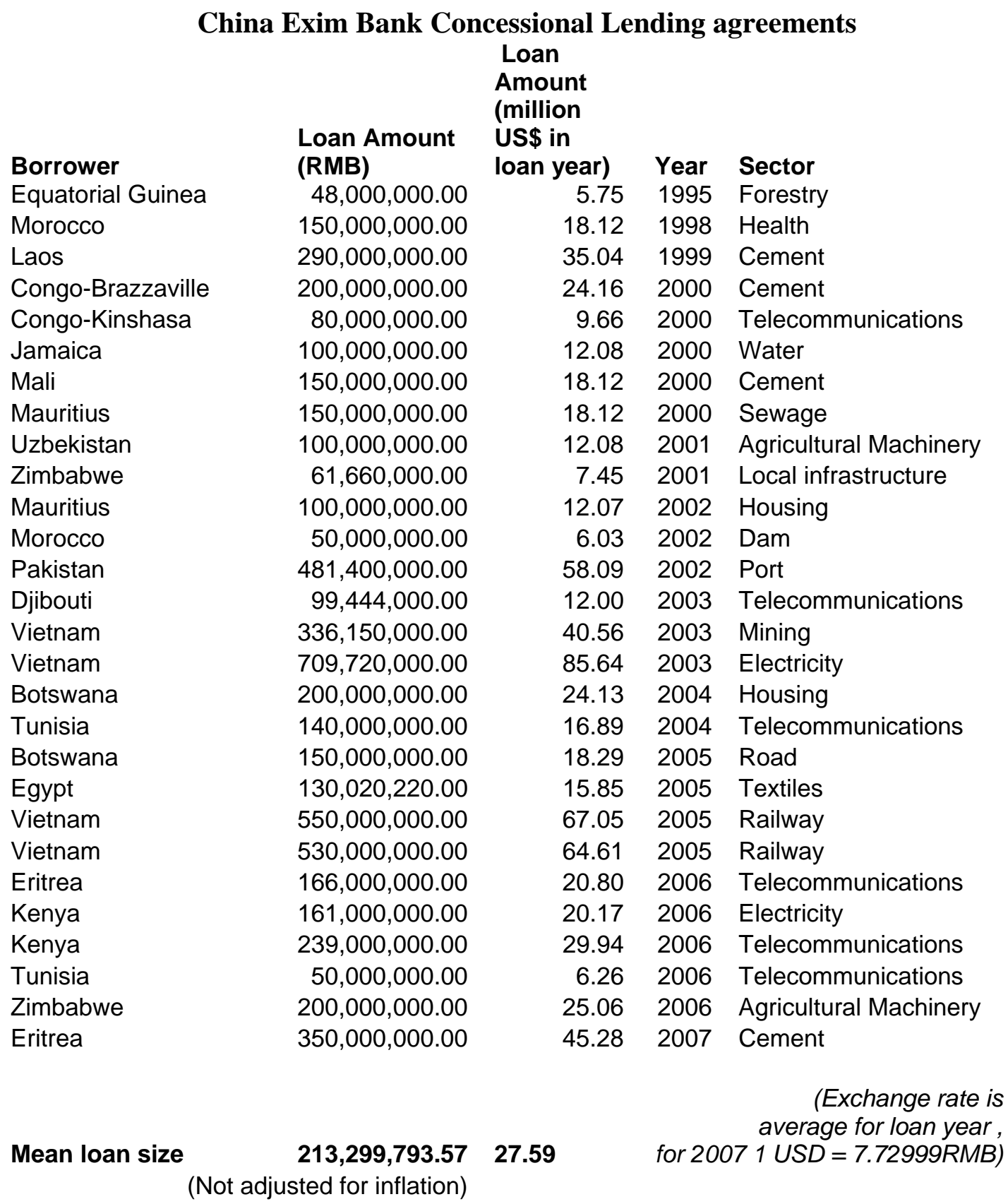

Page 6 of 17 
This process has identified 5.9 billion Renminbi (US\$773) worth of loans made between 1998 and 2007. The mean loan size is 213 million Renminbi (US\$28 million). This suggests that the scale of China Exim Bank concessional lending has increased significantly since 2000 , when the mean loan size per project (based on the last available figures) was 67.8 million Renminbi (US\$8.2 million). ${ }^{12}$

\section{Does this count as Official Development Assistance?}

Without knowing the terms of the loan, it is difficult to determine whether concessional lending would qualify as Official Development Assistance. ${ }^{13}$ Unfortunately it is these very terms which are not available in the Chinese sources. The Chinese do not prevent recipients for revealing the terms, which happened in six of the above cases. Loan terms have further been revealed in six cases (for which I do not have authoritative Chinese source material). Relying on these 12 cases, the concessional loans appear to be provided for a term of between 10-20 years (mean is 15.5 years), at an interest rate between $2 \%$ $4 \%$ (mean $2.85 \%$ ) and a grace period between $3-7$ years. This is consistent with what Brautigam has described. ${ }^{14}$

Even if the terms of the loan are concessional, only loans "with promotion of economic development and welfare as the main objective" are classified as Official Development Assistance. ${ }^{15}$ Here it is interesting to consider an article that appeared in The Market Daily, a publication of the People's Daily, which was part of a series aimed at Chinese enterprises on trade and investment in Africa.

The article suggests that the purpose of Chinese concessional lending is more to do with export promotion than economic development. It begins by advising Chinese firms that "[i]n order to support and assist Chinese firms doing trade and business in Africa overcome the problem of insufficient funding, the Chinese government has already signed reduced interest concessional loan framework agreements with 26 African countries." 16 The Chinese firm should "purchase and import from China as much equipment, technology and services as possible". The host site should have "plentiful local resources, a vast market for goods, favorable economic prospects".

The advice does note that the project must be "capable of promoting the host country's economic development" and the consent of the host government is required before the project can go ahead. Nevertheless, the loans retain a strong commercial flavor. The requirement that "the government of the host country will need good credit and be

\footnotetext{
${ }^{12}$ Xinhua, 23 October 2000, assuming the total of 4.678 billion renminbi reported here for 69 projects does not include non-concessional lending.

${ }^{13}$ According to the terms of the Organisation for Economic Cooperation and Development's (OECD)

Development Assistance Committee (DAC)

${ }^{14}$ Brautigam 2007

${ }^{15}$ See OECD DAC glossary,

http://www.oecd.org/glossary/0,3414,en_2649_33721_1965693_1_1_1_1,00.html\#1965586

${ }^{16}$ Huang Zequan, 22 October 2004 (see translation in Appendix C)
} 
capable of servicing the debt" is a further indication that the Chinese government is not presently planning to forgive these debts.

If these loans would in fact qualify as Official Development Assistance, then it is notable that this is provided to countries which receive very little development assistance in the form of concessional loans, particularly Botswana and Mauritius on account of relatively large GDP, or Zimbabwe, on account of its political isolation. Compounding the significance of providing the lion's share of concessional lending amongst certain recipients is the clear preference for infrastructure projects, which may respond both recipient demand and Chinese expertise.

\section{Conclusion}

By using the open Chinese sources, it is possible to gain a greater understanding of China Exim Bank's concessional loans, than reliance only on English language sources. The formation of loan agreements is sometimes reported with details of the size of the loan and its intended purpose. The Chinese government seems comfortable with releasing this information, which boosts the status of China both domestically and internationally.

Although Chinese language sources are vital in providing some of these details which might otherwise be missed, they are unfortunately incomplete in that they do not report all, or even the majority of concessional loans that are made. They allow us to better educate our guesses about typical loan size and sector, but do not provide enough information with which to analyze Chinese lending systematically.

Sporadically between 1997 and 2004, the Chinese government did release in the press details of the number of projects, countries, and approximate size of the concessional lending program. In order to build confidence internationally, and to provide a clearer picture of China's development policies, the Chinese government could begin publishing these aggregate statistics in the annual report of China Exim Bank.

Likewise, it would not be difficult for the Ministry of Foreign Affairs to publish a list of countries with which China has a concessional loan framework agreement, and for the China Exim Bank to publish a list of project agreements signed with recipient governments. Given that the Chinese government has already shown a willingness to publish this kind of information, there is no barrier to it being released on a regular basis as a complete set.

However, there remains information which the Chinese government has so far been unwilling to provide publicly. This includes the terms of the loan, and information on interest payments and debt forgiveness. This data is important for the analysis of official aid flows, and for other donors to coordinate their own development assistance. What is unclear is whether China, for political reasons, prefers to maintain strict confidentiality, or whether the China Exim Bank does not effectively monitor its lending program. 
One plausible reason for China Exim Bank's reluctance to reveal details of its concessional loans is the desire to protect commercial confidentiality of Chinese exporters. The advice on applying for concessional loans that was given to exporters suggests that the primary purpose of it is to provide capital to Chinese exports. The economic development of recipient country is a condition of the loan, but not its dominant purpose. In this case, the exporting firm has a competitive commercial incentive not to reveal the terms of its financing. Likewise, the Chinese government may give greater weight to the particular commercial interests of its domestic firms, rather than the international public interest in transparency. The problem for China is that this secretive approach bolsters suspicions that China is only in Africa for commercial exploitation.

An alternative explanation is that the loans would not in technically qualify as Official Development Assistance when compared against the guidelines of the DAC donors. By maintaining some ambiguity, the Chinese government may be attempting to generate goodwill as a donor from what might be better characterized as more commercial lending.

If China would rather establish its credentials as a responsible aid donor, it will need to join the international track in terms of recognizing major donor lending norms. Transparency does not need to change the character of Chinese lending. Indeed, the Chinese model, by harnessing the self-interest of Chinese firms in developing loan projects, appears to enjoy the virtue of supply side sustainability. But to create sustainable demand for Chinese development capital, China will need to reassure the developing world of its good intentions. Greater transparency will provide some of this reassurance. 


\section{Appendix A}

\section{中国政府与厄立特里亚政府签署优惠贷款框架协议}

2006 年 4 月 11 日，中国政府向厄立特里亚政府提供优惠贷款框架协议签字仪式在 厄首都阿斯马拉举行, 中国驻厄大使舒展和厄国家发展部长乌代分别代表各自政府 在协议上签字。

根据协议, 中国进出口银行将向厄方提供 1.66 亿元人民币 ( 2300 万美元) 优惠贷 款, 用于改造厄通讯网。项目工期一年半, 建成后将更新升级厄通讯网现有设备, 使固定电话网覆盖厄主要城市, CDMA 无线网基本覆盖厄全境及沿海岛屿，电信 普及率将由目前的 $1.5 \%$ 上升至 $6.5 \%$, 从而有力地支持厄经济建设, 并推动我高科 技电信产品出口。

乌代部长当场表示, 这是两国互利合作的又一个新开端。12 日，厄官方报纸《厄 形象报》报道称, 此项目为落实厄总统伊萨亚斯 2005 年 2 月访华成果之一。

\section{Governments of China and Eritrea sign Concessional Loan Framework Agreement.}

11 April 2006 - The Chinese Government has signed a framework agreement to provide a concessional loan to the government of Eritrea at a ceremony held in the Eritrean capital Asmara. Representing the governments at the signing were the Eritrean Minister for National Development, Woldai, and the Chinese Ambassador to Eritrea.

According to the agreement, the China Exim Bank will advance a 166 million Renminbi (23 million USD) loan to Eritrea to upgrade its communications network. The 18 month project includes: upgrading the facilities of the existing Eritrean communications network, ensuring that principal Eritrean cities are covered by the telephone network, a wireless CDMA network to cover the entire country and coastal islands and increasing the existing telephone subscription rate from $1.5 \%$ to $6.5 \%$. This supports Eritrean economic development, as well as promoting our own high-tech telecommunications exports.

At the ceremony, Minister Woldai stated that this was a new beginning for mutually beneficial cooperation between the two countries. The official newspaper, Hadas Eritrea, on the $12^{\text {th }}$ described the agreement as a positive result of President Isaias' February 2005 visit to China.

(source: http://www.gov.cn/zwjw/2006-04/13/content 253071.htm, translated by Paul Hubbard) 


\section{Appendix B}

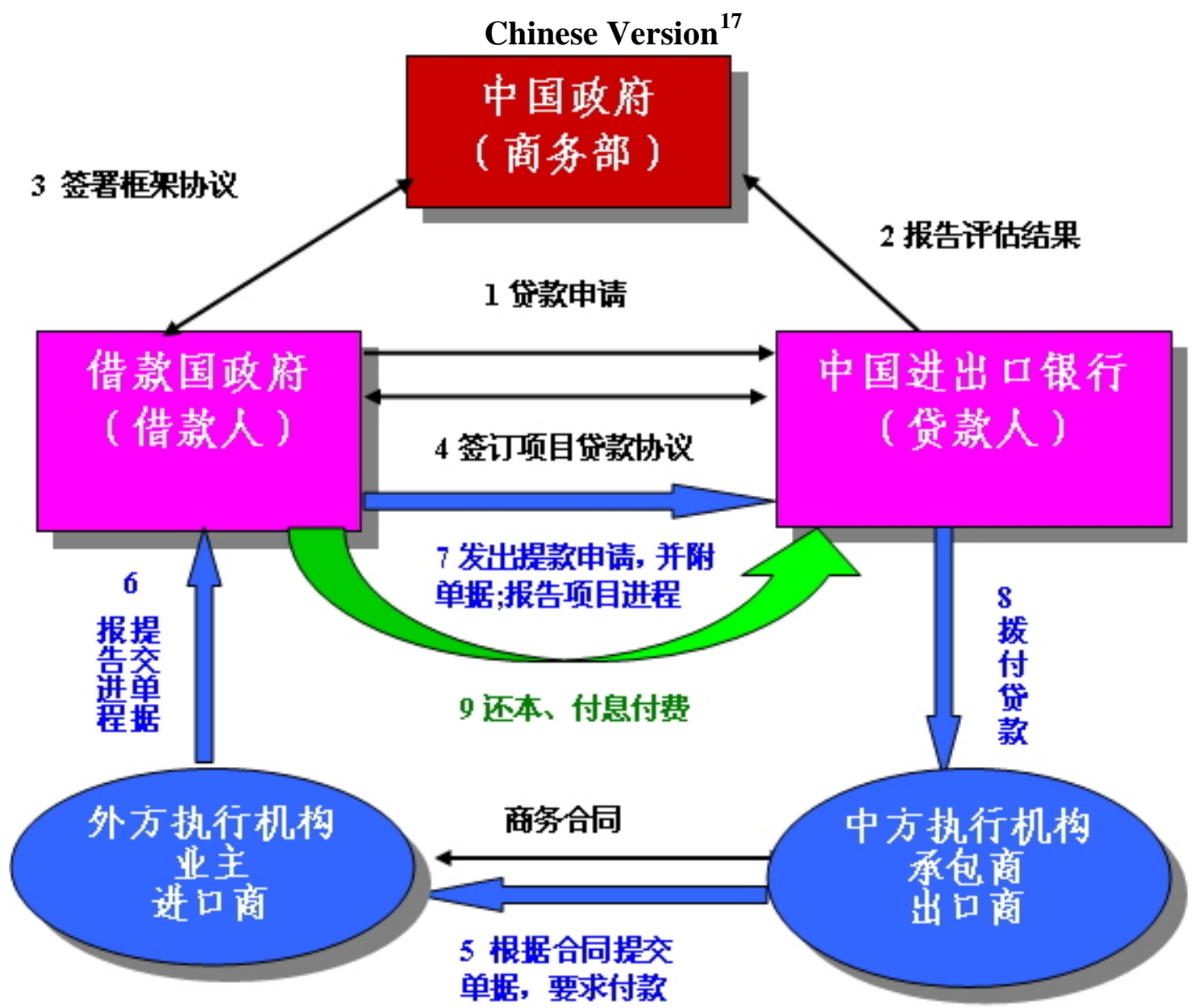

1. The government of the borrowing country submits an application to the China Exim Bank.

2. China Exim Bank reports the evaluation to the Ministry of Commerce

3. The Chinese Government signs a framework agreement with the borrowing country.

4. The borrowing government signs a project agreement with the China Exim Bank.

5. According to the contractual terms, the Chinese contractors and exporters invoice the foreign executing agency requesting payment.

6. The foreign executing agency submits the invoice and progress report to the borrowing country government.

7. The foreign government submits a drawing application, invoice and progress report to the China Exim Bank.

8. China Exim Bank then disburses the funds to the exporter.

9. The foreign government pays interest and fees and loan repayments to China Exim Bank.

\footnotetext{
${ }^{17}$ (Source: China Exim Bank http://www.eximbank.gov.cn/yewu/duiwaiyh.jsp)
} 


\section{English Version $^{18}$}

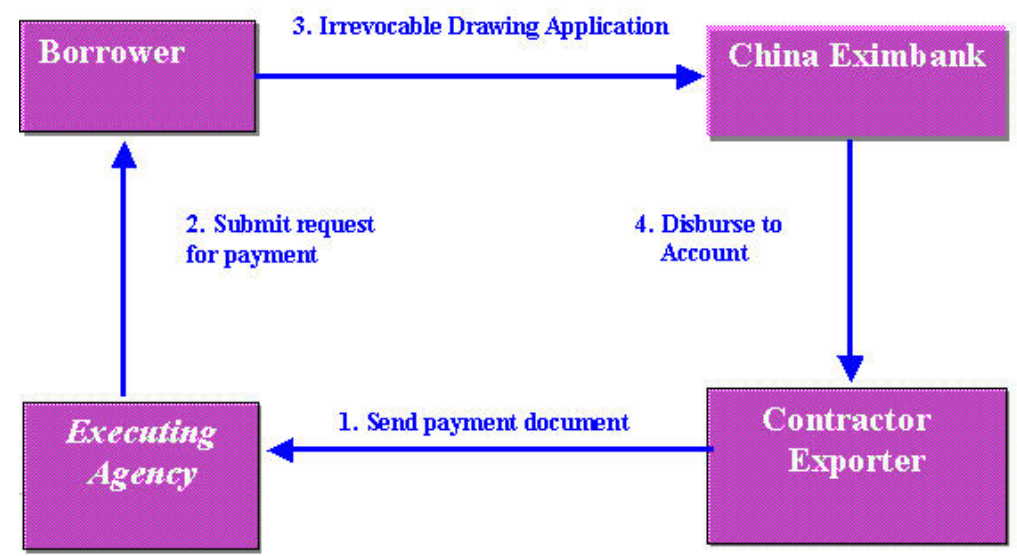

${ }^{18}$ (Source: China Exim Bank http://english.eximbank.gov.cn/business/government.jsp) 


\section{Appendix C}

【报刊名称】市场报 - The Market Daily

【肩标题】《如何在非洲贸易投资之六》“How to trade and invest in Africa - Part VI"

【标题】如何申请优惠贷款 ( 投资非洲 ) How to apply for a concessional loan (Invest in Africa)

【副标题】

【版次】第十八版 - Issue 18

【版名】环球·盈利机会 - Global Profit Opportunity

【日期】 2004.10 .22

【作者】ロ本报记者 黄泽全 - Staff correspondent: Huang Zequan 【内容】

中国政府为了支持和帮助中国企业到非洲投资办实业解资金不足问题，已经同苏 丹、肯尼亚、赞比亚、坦桑尼亚、加蓬、喀麦隆、加纳和莫桑比克等 26 个非洲国 家签订了政府间贴息优惠贷款框架协议, 中国企业只要在这些非洲国家找到合适项 目，便可以申请这种贴息优惠贷款。

中国企业申请政府间贴息优惠贷款必须具备如下基本条件：项目所在国与中国 签订有政府间贴息优惠贷款框架协议，企业在探讨项目的开始阶段或在项目运作过 程中，须及时向中华人民共和国商务部对外援助司了解所操作的项目是否符合优惠 贷款的使用方向；项目所在国政治局势相对稳定，经济建设状况比较良好; 项目符 合中国政府和所在国政府的有关政策，并且得到所在国政府同意; 借款人和担保人 资信良好, 具有偿还能力和代偿能力; 所选投资项目为生产性, 当地资源丰富, 产 品具有广阔市场，项目经济效益良好，能够促进所在国经济发展; 所选投资项目属 基础设施或设备引进, 所在国政府需要具备良好信誉和偿债能力; 项目申请、实施 单位具有较强的经济技术实力和国际经营管理能力; 项目借贷金额一般不低于 100 万美元, 项目所需设备、技术和服务应最大限度地从中国采购或引进; 项目的配套 资金、设备等条件得到落实。

申请程序为：(一) 符合上述条件的项目，企业可向商务部援外司提出申请， 并提交有关资料。商务部初审合格后, 向中国进出口银行推荐。(二) 中国进出口 银行接到商务部正式推荐函件后, 开始对项目进行可行性评估, 但需要企业提供的 材料有正式贷款申请; 项目可行性报告; 申请贷款企业资格证明（包括企业情况介 绍、营业执照、公司章程等 ); 企业经审计合格的近 3 年财务报表 ; 担保人情况和 
近 3 年财务报表; 与非洲合作伙伴商务合同（如果是合资项目，应当提供合资合同 和章程、对方合作伙伴的资信情况介绍等 ）；有关非洲国家政府批准或支持该项目 的有效书面文件; 中国进出口银行所需要的其它有关文件。中国进出口银行经过评 估，认为项目可行，将与借款人商签贷款协议，与担保人签订担保合同。

In order to support and assist Chinese firms doing trade and business in Africa overcome the problem of insufficient funding, the Chinese government has already signed reduced interest concessional loan framework agreements with 26 African countries, including Sudan, Kenya, Zambia, Tanzania, Gabon, Cameroon, Ghana and Mozambique. Chinese firms only need to find a suitable opportunity within these African countries in order to apply for one of these types of low interest concessional loans.

Chinese firms applying for an intergovernmental low interest concessional loan must meet the following basic conditions: the project must be located in a country with which China has signed a concessional loan framework agreement, at the beginning of the project, and during progress operations, the firm must inform the People's Republic of China, Ministry of Commerce Foreign Assistance Office whether or not the project operations are in accordance with the terms of the loan; the country in which the project is located must have a relatively stable political situation and favorable conditions for economic growth; the project must be in line with relevant policies of the Chinese government and the host government, and must obtain the consent of the host government; the lender and guarantor must have good credit and the capacity to repay; the investment project should be in manufacturing, with plentiful local resources, a vast market for goods, favorable economic prospects and capable of promoting the host country's economic development; the project should focus on infrastructure or the introduction of equipment, the government of the host country will need good credit and be capable of servicing the debt; the unit applying for and carrying out the project should have comparatively strong economic and technical strength and the capacity to manage foreign operations; the loan size should ordinarily be at least US \$1 million, and should purchase and import from China as much equipment, technology and services as possible; the project's supplementary funding, equipment etc; conditions must be implemented.

Application Procedure: 1) In accordance with the abovementioned conditions, the firm must submit an application to the Foreign Assistance Office in the Ministry of Commerce, along with supporting material. After the Ministry of Commerce has initially approved the project, it will submit a recommendation to the China Exim Bank. 2) After receiving the official letter of recommendation, the China Exim Bank will conduct a feasibility study of the project, using the official application and supporting material provided by the firm; the feasibility report; the credentials of the firm applying for the loan (comprising the firm's situation, licenses, company regulations etc.); a 3 year audit of the firm's certified financial report; the guarantor's situation and 3 year financial audit; a commercial contract with an African joint cooperative partner (if it is a joint venture, the joint venture rules and contract, and the partner's credit situation, etc. should be provided); an effective written document showing the African country's government 
approval or support for the project; and any other relevant documentation required by the China Exim Bank. The China Exim Bank will perform an evaluation, consider the feasibility of the project, and will then sign agreements with the borrower and the guarantor.

(source http://www.people.com.cn/GB/paper53/13217/1185583.html, translated by Paul Hubbard) 


\section{Appendix D}

\begin{tabular}{|c|c|c|c|c|}
\hline Year & $\begin{array}{l}\text { Treaty } \\
\text { Number }\end{array}$ & Date Signed & Country & Signed at \\
\hline 2004 & 24 & 2004-02-18 & Jamaica & Beijing \\
\hline 2004 & 29 & 2004-02-24 & Suriname & Beijing \\
\hline 2004 & 42 & 2004-03-18 & Laos & Vientiane \\
\hline 2004 & 51 & 2004-03-28 & Maldives & Male \\
\hline 2004 & 63 & 2004-04-20 & Cambodia & Beijing \\
\hline 2004 & 111 & 2004-06-22 & Syria & Beijing \\
\hline 2004 & 113 & 2004-06-24 & Togo & Kara \\
\hline 2005 & 7 & 2005-01-29 & Venezuela & La Paz \\
\hline 2005 & 9 & 2005-01-31 & $\begin{array}{c}\text { Trinidad and } \\
\text { Tobago }\end{array}$ & Port of Spain \\
\hline 2005 & 30 & 2005-04-07 & Bangladesh & Dhaka \\
\hline 2005 & 54 & $2005-05-25$ & Mongolia & Ulan Bator \\
\hline 2005 & 95 & 2005-07-18 & Vietnam & Beijing \\
\hline 2005 & 106 & 2005-08-03 & Togo & Lome \\
\hline 2005 & 116 & 2005-08-17 & Kenya & Beijing \\
\hline 2006 & 37 & 2006-04-03 & Tajikistan & Beijing \\
\hline 2006 & 44 & 2006-04-04 & Fiji & Suva \\
\hline 2006 & 42 & 2006-04-04 & Philippines & Manila \\
\hline 2006 & 55 & 2006-04-06 & Yemen & Beijing \\
\hline 2006 & 129 & 2006-07-10 & Zambia & Lusaka \\
\hline 2006 & 165 & 2006-09-07 & Congo-Kinshasa & Kinshasa \\
\hline 2006 & 218 & 2006-11-30 & Benin & Cotonou \\
\hline
\end{tabular}

${ }^{19} 2006 \mathrm{http} / /$ www.fmprc.gov.cn/chn/wjb/zzjg/tyfls/tfsckzlk/zgywgsbtyylb/t310145.htm $2005 \mathrm{http}: / /$ www.fmprc.gov.cn/chn/wjb/zzjg/tyfls/tfsckzlk/zgywgsbtyylb/t237097.htm 2004 http://www.fmprc.gov.cn/chn/wjb/zzjg/tyfls/tfsckzlk/zgywgsbtyylb/t268739.htm $2003 \mathrm{http}: / /$ www.fmprc.gov.cn/chn/wjb/zzjg/tyfls/tfsckzlk/zgywgsbtyylb/t140216.htm $2002 \mathrm{http} / / /$ www.fmprc.gov.cn/chn/wjb/zzjg/tyfls/tfsckzlk/zgywgsbtyylb/t142225.htm 


\section{References}

Africa News Eritrea And China Conclude Loan Agreement, 4 July 2006

Brautigam Deborah, China's Foreign Aid in Africa: What do we know? Paper prepared for Conference on CHINA IN AFRICA: GEOPOLITICAL AND GEOECONOMIC CONSIDERATIONS 31 May - 2 June 2007, J. F. Kennedy School of Government, Harvard University

China Daily Bank broaches concessional loan rethink, 18 May 1998 Eximbank to Finance Equipment Exports, 4 August 1997

Harris Ed, Eritrea says received \$23 mln loan from China, Reuters, 12 April 2006

Huang Zequan, "How to apply for a concessional loan (Invest in Africa)", Market Daily, 22 October 2004

People's Daily, 进出口银行已向四十多个发展中国家提供融资, 28 December 2002

People's Daily Overseas Edition, The Economic and Cultural Wave, 26 February 2001

Xinhua, Eximbank provides loans for Vietnam, 23 October 2000 